IZA DP No. 1244

The Influence of Others on Migration Plans

Gil S. Epstein

Ira N. Gang

August 2004 


\title{
The Influence of Others on Migration Plans
}

\author{
Gil S. Epstein \\ Bar-llan University, CEPR and IZA Bonn \\ Ira N. Gang \\ Rutgers University and IZA Bonn
}
Discussion Paper No. 1244
August 2004

\author{
IZA \\ P.O. Box 7240 \\ 53072 Bonn \\ Germany \\ Phone: +49-228-3894-0 \\ Fax: +49-228-3894-180 \\ Email: iza@iza.org
}

\begin{abstract}
Any opinions expressed here are those of the author(s) and not those of the institute. Research disseminated by IZA may include views on policy, but the institute itself takes no institutional policy positions.

The Institute for the Study of Labor (IZA) in Bonn is a local and virtual international research center and a place of communication between science, politics and business. IZA is an independent nonprofit company supported by Deutsche Post World Net. The center is associated with the University of Bonn and offers a stimulating research environment through its research networks, research support, and visitors and doctoral programs. IZA engages in (i) original and internationally competitive research in all fields of labor economics, (ii) development of policy concepts, and (iii) dissemination of research results and concepts to the interested public.
\end{abstract}

IZA Discussion Papers often represent preliminary work and are circulated to encourage discussion. Citation of such a paper should account for its provisional character. A revised version may be available directly from the author. 
IZA Discussion Paper No. 1244

August 2004

\section{ABSTRACT}

\section{The Influence of Others on Migration Plans*}

The willingness to migrate and locational choice may be influenced by others' choices or plans, particularly if the "other people", such as family and friends, are migrants, former migrants, or potential migrants themselves. We examine the roles "other people" play in influencing an individual's potential migration decision. In analyzing the influence of others on migration decisions, we rely on the concepts of migration networks and herd effects.

JEL Classification: F22, J61

Keywords: migration, networks, herds, transition

Corresponding author:

Ira N. Gang

Economics Department NJH

Rutgers University

75 Hamilton St.

New Brunswick NJ 08901-1248

USA

Email: gang@economics.rutgers.edu

\footnotetext{
" Ira Gang thanks the Rutgers' Research Council for partial support. This paper was partly written while both authors were visiting IZA, Bonn and Ira Gang was visiting Bar-Ilan University. We thank MyeongSu Yun for helpful discussions.
} 


\section{Introduction}

A striking characteristic of immigrant communities is ethnic clustering. Concentrations of Turks are found in Germany, Tamils in Switzerland, Moroccans in the Netherlands and Belgium, Italians in Argentina, Greeks in Australia, and Ukrainians in Canada. Clustering can be very narrow, such as when immigrants from a town or region are concentrated in the one foreign town or region. Often we find intricate family links.

It is doubtful that the clustering we observe is an accident. Potential migrants, in making their decisions about whether to go abroad and where to locate, take into account the decisions of others. Conventional models of migration focus on the utility or income gains migrants can expect from moving, though when cast in terms of the costs and benefits of migration anything can be included. Over the last decade or so, the role of family, village and ethnic networks in the migration decision has come to be emphasized. We study friends and family who have gone abroad and returned, who are abroad, and who are planning to go abroad, and suggest that one of the major influences on both the decision to go abroad and the decision of where to go is the role that "other people" play. Ethnic clustering may result.

Why should the decisions of others exert such a strong influence on migration choices? One reason is the existence of beneficial network externalities. Network externalities arise when previous immigrants provide shelter and work, assistance in obtaining credit, and/or generally reduce the stress of relocation to a foreign culture. Network externalities imply "I will go to where my people are, since it will help me." On the other hand, immigrant clustering may be due to "herd behavior," where the migrant "follows the crowd." Here, the migrant goes where recent emigrants have gone, not because of positive externalities, but because "all those others who went before me cannot be wrong, even though I would have chosen independently to go elsewhere." Herd behavior offers an information perspective on why migrants from the same location make the same foreign relocation decision.

In thinking about the emigration decision the potential migrant takes into account a number of considerations. These include potential wealth and income gains, the benefit or stress of leaving home, and the risks and costs of migration. If one's family or friends are also contemplating emigration, or if ones family or friends are already abroad, network and herd theory tell us that these influence the potential migrant to more strongly consider emigrating, and if he knows where they are or where they plan on going, it will affect locational choice. 
Our study examines the migration intensions of Hungarians in 1993/94. Hungary began its liberalization early. Long before the fall of the Berlin Wall a substantial number of Hungarians emigrated, some settling permanently abroad, some staying a long time, and many returning after brief work related trips. Moreover, the exodus that followed the failed 1956 revolution left Hungarian communities in a number of countries. We examine what determines whether an individual in Hungary plans to go abroad, what determines their willingness to go abroad, and what determines where they plan to migrate. From among the different alternative foreign locations for emigration, one location objectively offers better conditions than others. The identity of this best foreign location is often unknown to potential migrants, and the potential migrant gathers information from friends and family, and acquires knowledge of others' plans, in deciding whether and where to go.

The data we employ contains information that is useful in examining the connections between potential migrants and existing and potential networks and herds. However, it is important for us to point out that our paper is concerned with plans to go abroad and plans for which country to go to, not actual decisions. We do not have in our data information for those people who have migrated, the state of their knowledge about friends and families' decisions and intensions, or information on the state of their other relevant migration-determining factors at the time of their migration decision. Asking respondents whether they have plans to migrate misses an important element: the difference between declared intensions and realized actions. The old expression, 'there is many a slip between the cup and the lip', is particularly relevant. Yet, understanding the intentions of individuals' vis-à-vis their migration choices places something of an upper bound on the number and location decisions of realized migration in the near future.

In the next section we describe the related literature and the conceptual underpinnings of our analysis. Section 3 discusses the data and our probit analysis. Section 4 delves more into the details of how our respondents have been influenced by others in making their plans. Section 5 concludes.

\section{Literature and Theory}

We address the question "How do other migrants and potential migrants affect plans and willingness to go abroad, and the location choices of potential migrants?". Models of an individual's movement intentions or their willingness to go abroad have been estimated by 
several authors including Ahn, de la Rica, and Ugidos (1999) for Spain, Burda, Hardle, Muller, and Werwatz (1998) for Germany, Faini, Galli, Gennari, and Rossi (1997) for Italy, Hughes and McCormick (1985) and Drinkwater (2003a) for Great Britain, Drinkwater (2003b) for several of the European Union May 2004 accession countries, and Mintchev and Boshnakov (2004) for Bulgaria.

An important feature we emphasize in answering our question is the transmission of information from friends and family. Mincer (1978) first suggested that family ties have an important effect on migration. Mincer's argument provides the justification for including marital status and family composition variables in migration equations. Family ties, he argued, have a deterrent effect on the propensity to migrate. However, once kin or friends have gone abroad, the links to them may encourage migration and influence locational choices. The transmission of information is at the core of network and herd explanations of migration decisions.

Network explanations of migration decisions emphasize the role of social and informational networks as determinants of the decision to migrate and the where to migrate, as well as the duration of time abroad. Ties of kinship, friendship, and village, link migrants, former migrants, and non-migrants in the home and host country. In an uncertain environment, migration networks provide information about the labor market in the host country and thus may increase the expected wage and decrease uncertainty by enabling the migrant to obtain better paying and more stable jobs. Under network-externalities, costs of relocation decrease with the number of immigrants, which encourages more emigration.

There is a substantial literature on network externalities in migration. Beneficial network externalities arise when previous immigrants provide shelter and work, or assistance in obtaining credit, or generally reduce the stress of relocation to a foreign culture (see Carrington, Detragiache, and Vishwanath 1996, Gottlieb 1987, Grossman 1989, Marks 1989, Church and King 1983, and Chiswick and Miller 1996). Disadvantageous network externalities may arise if immigration is subject to adverse selection (high productivity immigrants do not wish lowproductive people to immigrate), limiting the number of immigrants who can benefit from network externalities. Recently, Bauer, Epstein and Gang (2004a,b) examined the relative importance of these different aspects of migration networks.

In the presence of beneficial externalities the utility gain from migration depends on: (1) the number of migrants who have previously immigrated and (2) how many people will 
immigrate in the future. Even if the wage in a country is relatively low, positive externalities may make that country an attractive location. For example: suppose $\mathrm{n}$ people have emigrated to country $j$ and one individual has emigrated to country number $k$, and the immigrant in country $j$ is better off than that of an immigrant in country $k$. It could however be that if $n$ migrants had migrated to country $k$ and one migrant to country number $j$, the migrant to country $k$ would have been better off than in country $j$ (if $n$ migrants had immigrated to that country).

Epstein (2002) has recently introduced the phenomenon of herd behavior as an influence on migration decisions. Potential migrants may have some private information but are imperfectly informed about the attributes of alternative foreign locations, and they observe previous migrants decisions. Potential migrants cannot, however, observe the information signal that was the basis for previous emigrants' decisions. Given the information available, each individual chooses a country to which to emigrate. The outcome is that migrants discount private information and duplicate a location that recent migrants have been observed to choose.

Herds may be an explanation for the creation of the mass of immigrants that is sufficient to attract others to join and enjoy the positive externalities of the network. Informational cascades also help us understand why we observe immigrants deciding to migrate to destinations where the negative externalities are stronger than the positive externalities of the network. The reason for this phenomenon is that individuals are uncertain regarding the effect of the network externalities and decide to follow the flow of migrants rather than the stock of immigrants. Finally, herd behavior enables us to understand how an individual makes a decision when there is more than one country that provides the immigrant with the same level of network externalities. Migrants will decide to follow the flow (herd behavior) of migrants.

Network and herd effects reflect different types of information. Migrants might be motivated to choose a location in order to benefit from the network externalities it has to offer. However, as a result of herd behavior, the migrant may choose a location on the supposition that recent previous migrants had information that he does not have. Migrants may choose to follow the flow, which is to migrate to the location recent migrants have been observed to choose, or where others are contemplating going.

Both network externalities and herd behavior coexist as explanations of why others matter in individuals' migration decisions. Consider the case when one individual has chosen to migrate to a country. A second individual receives a positive signal indicating emigration to a 
different country. If this latter individual chooses to follow the first migrant, then she knows all successors will follow for informational and payoff reasons (herd behavior and positive network externalities). If she chooses the other country, there is a positive probability that she will end up alone. So, while she may think that the basic payoff or utility from moving to the alternative country is as good as for the first country, the awareness of the positive network payoff will induce her to choose the location chosen by the first emigrant. On the other hand, if disadvantageous or negative externalities are present, ${ }^{1}$ incentives arise to move to new locations. An individual who has to make a decision will weigh the information she receives: where previous acquaintances have gone (and that they have gone), her observations on the flow of migrants and on expected flows, and other general information.

Networks and herds are important elements of migration decisions, and they are what we focus on in this paper. Moreover, we emphasize the specific knowledge and trail that comes from kin and friends. Other information of the 'conventional wisdom' type is, of course, available. And there are other variables that enter migration decisions. We account for these as best we can with our data; however, our stress is on the influence of kin and friends on thinking about migration. They can influence the expected income and utility gains from migration, as well as the 'comfort level' immigrants can attain in host countries.

\section{Data and Empirical Analysis}

Our data comes from the Hungarian Household Panel Survey, conducted by TARKI, 1992-1997, the Social Research Informatics Centre, Budapest University of Economics (Sik, 1995; Tarki, 1999). The reference population is Hungarian non-institutional households surveyed nation-wide on a yearly basis. Questions were asked concerning social status, wealth, income, economic and financial strategies of Hungarian households, and demographic and employment histories (changes in labor market position) of household members. We draw our cross-sectional sample from 1993 and 1994, where a more complete set of questions on migration and migration

${ }^{1}$ Gang, Rivera-Batiz and Yun (2002) provide a statistical analysis of the determinants of attitudes towards foreigners displayed by European sampled in the Eurobarometer surveys in 1988 and 1997. They show that those who compete against migrants in the labor market have more negative attitudes toward foreigners and, as the concentration of immigrants in the local population increases, the likelihood of negative attitude increases (a negative network externality effect). See also Bauer, Lofstrom and Zimmermann (2000). 
intensions, and links to others who have or are thinking about migrating, were asked. Our intention in this paper is to see the effect of others on respondents thinking about emigrating abroad. Berencsi and Sik (1995) provide a descriptive analysis of the intensions data. Our sample consists of individuals between 20 and 60 years old in 1994 . The age restriction is imposed in order to confine our attention to persons who are in their "working life."

Table 1 presents the means of the variables used in our analysis, for all observations and for those who plan to go abroad and those who do not. In our sample of 2491 respondents, 5.7 percent plan to go abroad. Of these, 53.9 percent have friends who have worked abroad, 72.3 percent have friends or relatives who are abroad, and 26.2 percent have friends or relatives who are also planning to go abroad. These figures stand in stark contrast to those who do not plan to go abroad. Of the 94.3 percent of the sample who do not plan to go abroad, 19.4, 38.6 and 6.7 percent, respectively have friends who have worked abroad, have friends or relatives who are abroad, and have friends or relatives who plan to go abroad. For each variable we test the null hypothesis that the mean for those who are planning to go abroad is equal to the mean for those who do not plan to go abroad. For all these variables and most of the others considered in this study, there are significant differences between those who plan to go abroad and those who do not.

Respondents were asked specify the strength of their desire to go abroad. With not willing $=0$, somewhat willing $=1$ and willing $=2$, the mean of our respondents score was 0.405 . For those who said they planned to go abroad it was 0.929 , while for those with no plans, 0.373 . Other variables we examine reveal some interesting differences between those who plan to go abroad and those who do not. While men make up 46.3 percent of our sample, they make up 66.7 percent of those planning to go abroad. Those who plan to go abroad have more years of schooling, were more likely to have previously lived abroad, are younger, single, with fewer children, more likely to be living in Budapest, and less likely to be not working, compared to those with no plans to go abroad. With the exception of number of children and working status, these differences are statistically different.

Although interesting, the analysis obtained from Table 1 can only be suggestive. In order to systematically identify effects of various family and friend influences on the potential migration decision, we carry out two probit analyses. In Table 2 we present a simple probit with planning to go abroad or not as the dependent variable. In this probit analyses, the probability of 
a respondent planning to emigrate is defined as $\operatorname{Prob}($ plan to emigrate $=1)=\Phi(X \beta)$, where $\Phi$ is a standard normal cumulative distribution function, $\beta$ is a set of estimated coefficients and $X$ includes various explanatory variables to be specified below. The issue of interest here is why some people are more likely to plan to go abroad, and some are less likely. In Table 3 we present the results from an ordered probit analysis with willingness to go abroad as the dependent variable. In both of these estimations the marginal effects we report tell us the effect on the probability that one is planning or willing to go abroad.

In Tables 2 and 3, in addition to explanatory variables capturing past (friends worked abroad), present (friends/kin abroad), and future (friends/kin planning on going abroad) networks and herds, we include in our analysis a number of background and demographic variables, which are normally included in the analysis of migration decisions. We examine differences in migration inclination based on gender $($ male $=1$, female $=0$ ), and we look at the generational impact reflected by the age of the potential migrant. We expect age to be inversely associated with the probability of planning or willingness to go abroad. We also include the variables \#children $<6$, \#children 6 to 16 which tells us the number of children less than 6 years of age living in the household where the respondent resides, and the number of children ages 6 to 16. The age structure of children may impact the propensity to migrate abroad. The other variables we include are years of schooling, whether the respondent has lived abroad, marital status, living in Budapest or not, and currently working or not.

What we find in Table 2 is very strong evidence that friends and family play an important role in shaping one's plans to go abroad or not. The dependent variable is "planning to go abroad or not." The probability one is planning to go abroad increases by 3.2 percent if friends have worked abroad and returned to Hungary. The influence of friends and family who are currently abroad is marginally significant and has half the impact. If one has friends and family currently abroad the probability of planning to go abroad increases by 1.5 percent. The bigger influence, twice as large, is by returnees. Although their knowledge of current labor market conditions may deteriorate, they provide key links and support for the network. Returnees can tell stories about life abroad, provide information about jobs, and potential migrants can learn directly from them.

A striking result we find in Table 2 is the influence of friends and family who are planning to go abroad. The usual network story is one of the existence of beneficial network 
externalities when previous immigrants provide shelter and work, assistance in obtaining credit, and/or generally reduce the stress of relocation to a foreign culture. However, here, while certainly beneficial network externalities are an important part of the story, the bigger influence, increasing the probability of planning to go by 5.1 percent, does not strongly reflect the impact of networks. What we are observing is a larger influence of herd behavior, where prior information (that of those who have been abroad and those who are abroad) is discounted and the current flow is emphasized. Here, going with someone, or someone else going, is more important than the information provided by others having gone and returned, or not returned. This is a story of "if you go, I go." Migrants want to go with someone else, or at least migrate if there are others doing the same.

Together, the influence of friends and family who are abroad, have been abroad, and are planning to go abroad affect persons plans to go abroad. The stronger influence is by those who are around and are planning to go abroad themselves. This places more weight on the herding story than on the network story. The other variables in the estimation of whether someone is planning to go abroad or not provide results that are both logical and significant. The probability of planning to go is higher for males (3.2 percent), lower if married (-2.7 percent), lower if working (-1.6 percent). Each additional year of schooling raises the probability of migrating by 0.3 percent, and every year one ages reduced the probability of migrating by -0.2 percent. The number of children and living in Budapest are not significant.

Table 3 presents our results from the ordered probit where the dependent variable is willingness to go abroad. In Table 2 we clearly differentiate between whether someone is planning to go abroad or not. In Table 3 we offer an alternative specification that highlights the strength and intensity of the desire to go abroad. Again, the plans of friends have the largest influence, with respondents 3.0 percent more willing and 7.7 percent somewhat more willing to go abroad if friends and relatively are planning to go. Here, however, we find some weakness in the variables that capture more of network type effects, with having friends who have worked abroad not significant, while having friends and relatives who are abroad significant, but with smaller influence in comparison to those who are planning to go abroad (1.2 percent instead of 3.0 percent for more willing, 2.9 percent instead of 7.7 percent for somewhat willing).

Gender, years of schooling, lived abroad or not, and age, are significant in Table 3 as they were in Table 2. Males differ from females by their stronger attitudes in favor of moving abroad. 
The more highly educated and prior visits abroad show a positive effect on emigration behavior. Married, working and having children $<6$ are not significant, but having children 6 to 16 lowers the probability that someone is willing to go abroad. Living in Budapest increases the willingness to go abroad.

The lesson from Tables 2 and 3 are quite clear. Others - friends and family - have great influence on people's migration intensions. Having friends who have worked abroad, having friends and relatives who are abroad, and having friends and relatives who are planning to go abroad tells us much about the migration potential of an individual. Most important are the plans of others, with secondary influence in comparison for networks, as people naturally tend to follow the herd. Both herds and networks provide varying degrees of assistance and information to potential migrants

\section{Patterns of Potential Migration}

Above we asked about people's plans to go abroad and the strength of their intensions to do so. We found that herd and network stories helped our understanding of the development of intentions. Another question we ask is, when they go abroad, where do they intend on going? We present evidence on this matter in Tables 4 and 5. Unfortunately, the number of people who provided answers to the appropriate survey question is issue is only a relatively small subsample of the data. Also, some people provided multiple responses. In Table 4 we compare where potential migrants say they are planning to move to with the relocation plans of the friends and family. We argue that this provides some evidence in support of the role of herds in potential migrants thinking. In Table 5 we compare where potential migrants say they are planning to move to with the current location of friends and family who are abroad. This, we argue that this provides some evidence in support of the role of networks in potential migrants thinking.

The leading destination for potential migrants is Germany, followed by Austria. Approximately 43 - 44 percent of potential Hungarian emigrants are oriented towards these two destinations. Another $30-33$ percent see Canada, England, France or the United States in their plans. The issue we want to address is the role of friends and family in driving this pattern. Tables 4 and 5 examine in detail about how closely a respondent's planned location choice reflects connections to the place that he might already have. 
In Table 4, in which we contrast where respondents plan go against where their friends or kin plan to go, we have 203 potential migrants who specified their destination choices (multiple responses are possible). They named 16 countries where they were planning to go, and 15 countries where friends and family are planning to go.

Is there an overall pattern? Do potential migrants plan to go where others plan to go? Looking at Table 4 we want to know whether the observations in cells are randomly distributed. If randomly distributed, it would mean that potential migrants do not take friends and family plans into account when making their decision. It would argue against the existence of herd effects in migration. Note that the diagonal of the matrix (highlighted) provides the number of cases in which potential migrants plan to move to countries friends and family are also thinking about. We test whether the number of cases on this diagonal is equal to, greater than or less then, the number we would expect to see if the plans of our potential migrants and the plans of their friends and relatives were determined independently. ${ }^{2}$ We reject independence at every significance level. That is, we reject the notion that pattern in table is random. We take this as evidence that where people plan to go is not random, and shows the impact of other's thinking on migrants thinking (or vice-versa). As such it is largely part of our herd story, though it is not distinguishable from some aspects of the network story. By bringing your own networks along, you can certainly lower some costs associated with living in the host country. We further see that potential migrants have a strong preference for closer countries.

In Table 5 we have information on 293 respondents linking potential migrants' desired relocation countries to where kin and friends are currently living. This table illustrates the strength of network effects. Here, the potential migrants want to take advantage of the help they can receive from family and acquaintances who have established themselves in potential migration destinations. Potential migrants in our sample are contemplating going to 22 countries, while they have friends and kin in 19 countries. Germany and Austria again dominate

\footnotetext{
${ }^{2}$ We have 16 countries where either the potential migrant plans to go, kin/friends plan to go, or both. This gives 256 possible cells, with $16 / 256=0.0625$ as the probability of any one cell being fixed if strictly random pattern. We examine the hypotheses, Ho: $\mathrm{p}=<0.065$ and $\mathrm{H}_{1}: \mathrm{p}>0.065$. With $x \sim N(n p, n(1-p))$, we have $x \sim N(12.6875,11.895)$. We reject Ho if $((x-12.6875) /(\sqrt{ } 11.895))$ $>1.65$. We reject Ho at all alpha, hence rejecting the random effects model. This result is robust and is unchanged whether we include or exclude other Europeans and other Americans, or Austria and Germany, or all four of these possibilities.
} 
as destination choices, figuring in the plans of 23 percent of our respondents. Our hypothesis testing again has us reject the null hypothesis of independence at all levels of alpha. This result is robust: if we remove the destination choices of Germany and Austria, we find the same results. We take this as evidence in support of the role of networks in potential migrants location choice.

\section{Conclusions}

The fear of a mass migration out of Hungary as the barriers to mobility fall is unfounded. The migration potential is low, below six percent of Hungary's population. One should remember that this six percent of the Hungary population encompasses all categories of potential migrants, including both short and long-term migrants.

This, however, is not the key point of our paper. Ethnic clustering is a characteristic of immigrant communities. Clustering can be very narrow, such as when immigrants from a town or region are concentrated in the one foreign town or region. Often we find intricate family links. Our study examines the migration intensions of Hungarians in 1993/94. We examine what determines whether an individual plans to go abroad, what determines their willingness to go abroad, and what determines where they plan to migrate. From among the different alternative foreign locations to emigrate, one location objectively offers better conditions than others. The identity of this best foreign location is often unknown to potential migrants, and the potential migrant gathers information from friends and family, and acquires knowledge of others' plans, in deciding whether and where to go.

We explore the role of family and friends in this potential migration planning. We examine the factors that underlie an individual's migration decision, i.e., their willingness to emigrate. Those with the greatest potential to migrate are younger, more highly educated, more urban, and male. Our data is not that of those who migrated, rather we look at the intentions of the potential migrants, or their willingness to migrate. It is clear, however, that an obvious problem with such data is that some potential migrants may intend on going, but never go. Alternatively, one may not plan to go because of the constraints on mobility, but when these constraints are relaxed, one's mind might change. It's very easy to claim that an individual would emigrate (in some communities this is a matter of prestige), however, it is much more difficult to carry out the decision and emigrate. 
As in other studies, here we established that employment (respectively the level of unemployment) is not among the leading determinants of emigration. Potential migrant are taken on almost equally among employed and unemployed.

We show that individuals may also be unwilling to move from one country to another even if other areas offer better prospects. Costs are very important in this respect, since it is likely that the individual will incur both pecuniary and non-pecuniary costs as a result of their move and these may be large enough to outweigh the potential gains offered. Networks are an important element in lowering costs of migration. Both networks and herds play a very important role in decision-making regarding the choice of location of migration. People go to where they have information. One type of information is the information one obtains from looking at what others do. Even more important, perhaps, we show is that people want to migrate with friends (herds). 


\section{References}

Ahn, Namkee, Sara de la Rica, and Arantza Ugidos (1999): "Willingness to Move for Work and Unemployment Duration in Spain”, Economica, 66(263), 335-57.

Bauer Thomas, Epstein, Gil S., Gang, Ira N. (2004a): "The Influence of Stocks and Flows on Migrants' Locational Choices", IZA working paper.

Bauer Thomas, Epstein, Gil S., Gang, Ira N. (2004b): "Three Measures of Migration Networks", IZA working paper.

Bauer, Thomas, Magnus Lofstrom, and Klaus F. Zimmermann, (2000): "Immigration Policy, Assimilation of Immigrants and Natives' Sentiments towards Immigrants: Evidence from 12 OECD-Countries," Swedish Economic Policy Review, 7(2), 11-53.

Berencsi, Zsuzsa and Endre Sik (19954): "Intentions to Emigrate and to Work Abroad in Hungary in 1993-1994," in Maryellen Fullerton, Endre Sik, and Judit Toth, eds, Refugees and Migrants: Hungary at a Crossrods, Budapest, Hungary:Institute for Political Science of the Hungarian Academy of Sciences, 129-142.

Burda, Michael, C., W. Härdle, M. Muller, and A. Werwatz (1998): "Semiparametric Analysis of German East-West Migration Intentions: Facts and Theory", Journal of Applied Econometrics, 13(5), 525-41.

Carrington, William J, Enrica Detragiache, and Tara Vishwanath (1996): "Migration with Endogenous Moving Costs” American Economic Review, 86(4), 909-30.

Chiswick, Barry R, and Paul W Miller (1996): "Ethnic Networks and Language Proficiency among Immigrants," Journal of Population Economics, 9(1), 19-35.

Church, Jeffrey, and Ian King (1983): "Bilingualism and Network Externalities", Canadian Journal of Economics, 26(2), 337-45.

Drinkwater, Stephen (2003a): "Estimating the Willingness to Move within Great Britain: Importance and Implications," Manuscript, University of Surrey.

Drinkwater, Stephen (2003b): "Go West? Assessing the Willingness to Move from Central and Eastern European Countries", Manuscript, University of Surrey.

Epstein, Gil. S (2002): "Informational Cascades and Decision to Migrate," IZA working paper 445.

Faini, Ricardo. G. Galli, P. Gennari, and F. Rossi (1997): "An Empirical Puzzle: Falling Migration and Growing Unemployment Differentials Among Italian Regions", European Economic Review, 41(3-5), 571-9. 
Gang Ira N., Francisco L. Rivera-Batiz, and Myeong-Su Yun, (2002): "Economic Strain, Ethnic Concentration and Attitudes towards Foreigners in the European Union", Manuscript. Rutgers University, Economics Department.

Gottlieb, Peter (1987): Making Their Own Way: Shorthorn Blacks’ Migration to Pittsburgh, 1916-30, Urbana: University of Illinois Press.

Grossman, James R. (1989): Land and Hope: Chicago, Black Southerners, and the Great Migration, Chicago, University of Chicago Press.

Hughes, Gordon. A., and Barry McCormick (1985): "Migration Intentions in the UK: Which Households Want to Migrate and Which Succeed?", Economic Journal, 95(0), 113-23.

Marks, Carole (1989): Farewell-We're Good and Gone: The Great Black Migration, Bloomington, Indian University Press.

Mincer, Jacob (1978): “Family Migration Decisions,” Journal of Political Economy, 86(5), 749773.

Mintchev, Vesselin and Venelin Boshnakov (2004): "Who is Leaving? Potential Migration from Bulgaria in the Beginning of the XXI Century," Manuscript. Institute of Economics at the Bulgarian Academy of Sciences.

Sik, Endre (1995): "Measuring the Unregistered Economy in Post Communist Transition," Eurosocial Report, 52, Vienna, Austria.

TARKI Data Archive (1999): "Hungarian Household Panel, 1992-1997” (version 3.0.1. on CD) Budapest: Social Research Informatics Center. http://www.tarki.hu/index-e.html. 
TABLE 1: SUMMARY STATISTICS

(standard deviations in parentheses)

\begin{tabular}{|c|c|c|c|}
\hline Variables & Overall & Plan to Go Abroad & $\begin{array}{c}\text { Do Not Plan to Go } \\
\text { Abroad }\end{array}$ \\
\hline Plan to Go Abroad & $\begin{array}{l}.057 \\
(.231)\end{array}$ & & \\
\hline $\begin{array}{l}\text { Willing to Go Abroad } \\
(0=\text { Not, } 1=\text { Somewhat, } \\
\text { 2=Willing) }\end{array}$ & $\begin{array}{c}.405 \\
(.618)\end{array}$ & $\begin{array}{c}.929 \\
(.753)\end{array}$ & $\begin{array}{l}.373^{*} \\
(.594)\end{array}$ \\
\hline $\begin{array}{l}\text { Have friends who } \\
\text { worked abroad }\end{array}$ & $\begin{array}{l}.214 \\
(.410)\end{array}$ & $\begin{array}{l}.539 \\
(.500)\end{array}$ & $\begin{array}{l}.194 * \\
(.396)\end{array}$ \\
\hline $\begin{array}{l}\text { Have kin/friends who } \\
\text { are abroad }\end{array}$ & $\begin{array}{l}.405 \\
(.491)\end{array}$ & $\begin{array}{l}.723 \\
(.449)\end{array}$ & $\begin{array}{l}.386^{*} \\
(.487)\end{array}$ \\
\hline $\begin{array}{l}\text { Have kin/friends who } \\
\text { are planning to go } \\
\text { abroad }\end{array}$ & $\begin{array}{c}.078 \\
(.268)\end{array}$ & $\begin{array}{c}.262 \\
(.442)\end{array}$ & $\begin{array}{l}.067 * \\
(.250)\end{array}$ \\
\hline $\begin{array}{l}\text { Gender }(\text { male }=1, \\
\text { female }=0 \text { ) }\end{array}$ & $\begin{array}{l}.463 \\
(.499) \\
\end{array}$ & $\begin{array}{c}.667 \\
(.473)\end{array}$ & $\begin{array}{l}.451^{*} \\
(.498)\end{array}$ \\
\hline Years of Schooling & $\begin{array}{l}10.444 \\
(2.675)\end{array}$ & $\begin{array}{l}11.454 \\
(2.383)\end{array}$ & $\begin{array}{l}10.383^{*} \\
(2.680)\end{array}$ \\
\hline Lived abroad or not & $\begin{array}{l}.057 \\
(.233)\end{array}$ & $\begin{array}{l}.206 \\
(.406)\end{array}$ & $\begin{array}{l}.049^{*} \\
(.215)\end{array}$ \\
\hline Age & $\begin{array}{c}39.338 \\
(11.674)\end{array}$ & $\begin{array}{l}31.426 \\
(9.529)\end{array}$ & $\begin{array}{l}39.813^{*} \\
(11.622)\end{array}$ \\
\hline Married & $\begin{array}{l}.695 \\
(.460)\end{array}$ & $\begin{array}{l}.440 \\
(.498)\end{array}$ & $\begin{array}{l}.711^{*} \\
(.454)\end{array}$ \\
\hline$\#$ children $<6$ & $\begin{array}{l}.279 \\
(.565)\end{array}$ & $\begin{array}{l}.262 \\
(.569)\end{array}$ & $\begin{array}{l}.280 \\
(.565)\end{array}$ \\
\hline \# children 6 to 16 & $\begin{array}{l}.522 \\
(.793)\end{array}$ & $\begin{array}{l}.440 \\
(.740)\end{array}$ & $\begin{array}{l}.527 \\
(.796)\end{array}$ \\
\hline $\begin{array}{l}\text { Living in Budapest or } \\
\text { not }\end{array}$ & $\begin{array}{l}.150 \\
(.357) \\
\end{array}$ & $\begin{array}{l}.248 \\
(.434) \\
\end{array}$ & $\begin{array}{l}.144^{*} \\
(.351) \\
\end{array}$ \\
\hline $\begin{array}{l}\text { Currently working or } \\
\text { not }\end{array}$ & $\begin{array}{l}.622 \\
(.485)\end{array}$ & $\begin{array}{l}.589 \\
(.494)\end{array}$ & $\begin{array}{l}.624 \\
(.484)\end{array}$ \\
\hline Sample Size & 2491 & 141 & 2350 \\
\hline \multicolumn{4}{|c|}{$\begin{array}{l}\text { Note: The null hypothesis tested is that the mean of those who plan to go abroad is equal to that } \\
\text { of those who do not plan to go abroad. * implies that the null is rejected at the .01 level of } \\
\text { significance ( } 2 \text {-tailed test). } \\
\text { Source: Hungarian Household Panel, 1993-94. }\end{array}$} \\
\hline
\end{tabular}


TABLE 2: PLANNING TO GO ABROAD, PROBIT

(dependent variable: planning to go abroad or not)

\begin{tabular}{|l|c|c|}
\hline Independent variables & $\begin{array}{c}\text { Coefficient Estimates } \\
\text { (standard errors) }\end{array}$ & $\begin{array}{c}\text { Marginal Effects } \\
\text { (standard errors) }\end{array}$ \\
\hline Have friends who worked & $.417^{*}$ & $.032^{*}$ \\
abroad & $(.130)$ & $(.013)$ \\
\hline Have kin/friends who are & $.238^{* * *}$ & $.015^{* * *}$ \\
abroad & $(.136)$ & $.009)$ \\
\hline Have kin/friends who are & $.536^{*}$ & $.051^{*}$ \\
planning to go abroad & $(.130)$ & $(.018)$ \\
\hline Gender (male=1, female=0) & $.488^{*}$ & $.032^{*}$ \\
& $(.100)$ & $. .007)$ \\
\hline Years of Schooling & $.047^{* *}$ & $.003^{* *}$ \\
& $(.021)$ & $(.001)$ \\
\hline Lived abroad or not & $.628^{*}$ & $.065^{*}$ \\
& $(.144)$ & $(.002)$ \\
\hline Age & $-.027^{*}$ & $-.002^{*}$ \\
& $(.005)$ & $(.000)$ \\
\hline Married & $-.373^{*}$ & $\left(.027^{*}\right.$ \\
& $(.119)$ & $-.010)$ \\
\hline \# children <6 & -.044 & $(.006)$ \\
\hline \# children 6 to 16 & $(.092)$ & .000 \\
& .003 & $(.004)$ \\
\hline Living in Budapest or not & $(.065)$ & .012 \\
& .177 & $(.009)$ \\
\hline Currently working or not & $(.121)$ & $-.016^{* *}$ \\
& $-.247^{*}$ & $(.007)$ \\
\hline Constant & $(.101)$ & $\left(.088^{*}\right.$ \\
& $-1.445^{*}$ & $(.019)$ \\
\hline Sample Size: 2491 & $(.297)$ & \\
Veall-Zimmermann Pseudo R-squared: .293 & \\
Log-likelihood: -420.652, Restricted Log-likelihood (beta=0): -541.839 \\
Chi-squared: 242.374 & & \\
* significant at $.01 ; * *$ significant at $.05 ; * *$ significant at .10. & \\
Source: Hungarian Household Panel, 1993-94. Calculations with Limdep 7.0 \\
\hline
\end{tabular}


TABLE 3: WILLINGNESS TO GO ABROAD, ORDERED PROBIT (dependent variable: willingness to go abroad)

\begin{tabular}{|c|c|c|c|c|}
\hline \multirow{2}{*}{$\begin{array}{l}\text { Independent } \\
\text { variables }\end{array}$} & \multirow{2}{*}{$\begin{array}{l}\text { Coefficient } \\
\text { Estimates } \\
\text { (standard } \\
\text { error) }\end{array}$} & \multicolumn{3}{|c|}{ Marginal effects } \\
\hline & & $\begin{array}{l}\text { Willing }=0 \\
\text { (not willing) }\end{array}$ & $\begin{array}{c}\text { Willing }=1 \\
\text { (somewhat } \\
\text { willing) }\end{array}$ & $\begin{array}{c}\text { Willing = } 2 \\
\text { (willing) }\end{array}$ \\
\hline $\begin{array}{l}\text { Have friends who } \\
\text { worked abroad }\end{array}$ & $\begin{array}{c}.077 \\
(.081)\end{array}$ & -.027 & .019 & .008 \\
\hline $\begin{array}{l}\text { Have kin/friends } \\
\text { who are abroad }\end{array}$ & $\begin{array}{c}.115^{* * * *} \\
(.069)\end{array}$ & -.040 & .029 & .012 \\
\hline $\begin{array}{l}\text { Have kin/friends } \\
\text { who are planning to } \\
\text { go abroad }\end{array}$ & $\begin{array}{l}.305^{*} \\
(.092)\end{array}$ & -.107 & .077 & .030 \\
\hline $\begin{array}{l}\text { Gender }(\text { male }=1 \text {, } \\
\text { female }=0)\end{array}$ & $\begin{array}{l}.167 * \\
(.053)\end{array}$ & -.059 & .042 & .017 \\
\hline Years of Schooling & $\begin{array}{l}.567 * \\
(.012)\end{array}$ & -.020 & .014 & .006 \\
\hline Lived abroad or not) & $\begin{array}{l}.394 * \\
(.104)\end{array}$ & -.138 & .099 & .039 \\
\hline Age & $\begin{array}{l}.035^{*} \\
(.003)\end{array}$ & .012 & -.009 & -.004 \\
\hline Married & $\begin{array}{l}-.043 \\
(.064)\end{array}$ & .015 & -.011 & -.004 \\
\hline$\#$ children $<6$ & $\begin{array}{l}-.033 \\
(.047)\end{array}$ & .012 & -.008 & -.003 \\
\hline \# children 6 to 16 & $\begin{array}{l}.085^{*} \\
(.035) \\
\end{array}$ & .030 & -.021 & -.009 \\
\hline $\begin{array}{l}\text { Living in Budapest } \\
\text { or not }\end{array}$ & $\begin{array}{l}.175 * * \\
(.074) \\
\end{array}$ & -.061 & .044 & .017 \\
\hline $\begin{array}{l}\text { Currently working } \\
\text { or not }\end{array}$ & $\begin{array}{l}.070 \\
(.058)\end{array}$ & -.025 & .018 & .007 \\
\hline Constant & $\begin{array}{l}.099 \\
(.169) \\
\end{array}$ & -.035 & .025 & .010 \\
\hline \multicolumn{5}{|c|}{$\begin{array}{l}\text { Sample Size: } 2491, \mathrm{Mu}(1): 1.161 \text { (standard error: .039) } \\
\text { Log-likelihood: }-1816.036, \text {, Restricted Log-likelihood (beta=0): }-2015.617 \\
\text { Chi-squared: } 399.162 \\
* \text { significant at .01; ** significant at .05; *** significant at .10. } \\
\text { Source: Hungarian Household Panel, 1993-94. Calculations with Limdep 7.0. }\end{array}$} \\
\hline
\end{tabular}


Table 4: Where Does One Go - I?

(Rows: Where respondent plans on going; Columns: Where are kin/friends planning to go)

\begin{tabular}{|c|c|c|c|c|c|c|c|c|c|c|c|c|c|c|c|c|}
\hline & England & Austria & a Belgium & France & Neth & Germ & Italy & Switz & $\begin{array}{l}\text { Other } \\
\text { Euro }\end{array}$ & India & Canada I & Mexico & USA & $\begin{array}{l}\text { Other } \\
\text { Amer }\end{array}$ & Aus & Total \\
\hline England & 4 & 1 & 1 & 3 & 3 & 8 & & 1 & 1 & & 1 & & 4 & & & 27 \\
\hline Austria & & 17 & & & & 11 & 1 & 1 & 1 & & 1 & & & & & 32 \\
\hline Belgium & 2 & & 1 & & & 1 & & & & 1 & & & & & 1 & 6 \\
\hline France & 1 & & & 9 & 4 & & & & & & 1 & & 1 & & & 16 \\
\hline Netherlands & & & & 3 & 1 & & & & & & & & & & & 4 \\
\hline Germany & 2 & 13 & 1 & 2 & 1 & 24 & 1 & 2 & 3 & 1 & 2 & & 2 & & 1 & 55 \\
\hline Italy & & 2 & & & & & 2 & 1 & & & & & & & & 5 \\
\hline Spain & & 1 & & & 1 & & & & & & & & 1 & & & 3 \\
\hline Switzerland & 1 & 2 & & & & 2 & 2 & 2 & & 1 & & & 1 & & & 11 \\
\hline Other Euro & 1 & 1 & & & & 3 & & & 1 & & & & 1 & & 1 & 8 \\
\hline Japan & & & & & & & & & & & 1 & & & & & 1 \\
\hline Canada & & & & 3 & 3 & 1 & & & & & 1 & & 1 & & & 9 \\
\hline Mexico & & & & & & 1 & & & & & & & & & & 1 \\
\hline USA & 1 & 1 & & 1 & 1 & 3 & & & 1 & & 1 & 1 & 4 & & & 14 \\
\hline Other Amer & & & & & & 1 & & & & & & & & 2 & & 3 \\
\hline Australia & & 3 & & & & 3 & & & & & & & 1 & & 1 & 8 \\
\hline Total & 12 & 41 & 3 & 21 & 14 & 58 & 6 & 7 & 7 & 3 & 8 & 1 & 16 & 2 & 4 & 203 \\
\hline
\end{tabular}


Table 5: Where Does One Go - II?

(Rows: Where respondent plans on going; Columns: Where are kin/friends) England Austria Belgium Czech France Greece Neth Germ Italy Spain Switz Sweden $\underset{\text { Euro }}{\text { Other }}$ Israel Canada USA ${ }_{\text {Zeal }}^{\text {Aust Africa }}$ Total

\begin{tabular}{|c|c|c|c|c|c|c|c|c|c|c|c|c|c|c|c|c|c|c|c|c|}
\hline \multirow[b]{2}{*}{ England } & & & & & & & & & & & & & Euro & & & & Zea & & & \\
\hline & 3 & 2 & & & & & & 2 & 1 & & & & & & & 5 & & & 1 & 14 \\
\hline Austria & 1 & 11 & & & 1 & & & 26 & 1 & & 1 & & 2 & & & 1 & & & & 44 \\
\hline Belgium & & & & & & & & 1 & & & & & & & & & & & & 1 \\
\hline Finland & & & & & & & & 1 & & & & & & & & & & & & 1 \\
\hline France & & 2 & 1 & & 5 & & 3 & 7 & 2 & & & & & 1 & & 1 & & & & 22 \\
\hline Neth & & 1 & & & 3 & & 2 & 5 & & & & & & & & & & & 1 & 12 \\
\hline Norway & & & & & & & & & 1 & & & & & & & & & & & 1 \\
\hline Italy & & 1 & & & & & & 4 & & & & & & & & & & & & 5 \\
\hline Spain & & & & & & & & & 1 & & & & & & & & & & & 1 \\
\hline Switz & & & & & & & & 4 & & & & 1 & & & & 2 & & & & 7 \\
\hline Sweden & & 1 & & & & & & 2 & & & & 2 & & & & 2 & 1 & 1 & & 9 \\
\hline Ireland & & 1 & & & & & & 1 & & & & & & & & & & & & 2 \\
\hline Other Euro & & 1 & & & & & & 3 & 1 & & & & 2 & & & 1 & & & & 8 \\
\hline Brazil & & & & & & & & & & & & & & & & 1 & & & & 1 \\
\hline Canada & 1 & 1 & 3 & & 5 & & 3 & 13 & & & & & & 4 & 3 & 2 & & & 1 & 36 \\
\hline Mexico & & & & & & & & & & & & & & & & 1 & & & & 1 \\
\hline USA & 1 & 1 & & & & & & 2 & 1 & & & 2 & & & & 5 & & 2 & 1 & 15 \\
\hline Other Amer & & & & & & & & 4 & & & & & & & & & & & & 4 \\
\hline Australia & & & & & & & & 6 & & & & 3 & & & & 4 & & 1 & & 14 \\
\hline Total & 9 & 32 & 4 & 1 & 16 & 1 & 8 & 138 & 13 & 1 & 2 & 10 & 6 & 7 & 3 & 32 & 1 & 4 & 5 & 293 \\
\hline
\end{tabular}

